\title{
A PERCEPTIONAL STUDY ON THE TYPE OF WORK WOMEN UNDERTAKE IN TOP POSITION IN SELECTED SERVICE SECTOR WITH SPECIAL REFERENCE TO PUNE
}

\author{
Dr. Harini Rajan \\ Assistant Professor, MBA department, JSPM's Jayawant Institute of Management Studies \\ Pune-33 \\ (E-mail ID: harinimrajan@gmail.com ) \\ Mobile: 8956737461.
}

Dr. Anuja Johri

Associate Professor

(E-mail ID:dranuja.johri@gmail.com)

Mobile: 8830354529

\begin{abstract}
India has one of the lowest female labor force participation rates in the world and a majority of women work in the informal sector. The World Economic Forum said that at the it will take India 108 years to close the overall gender gap and 202 years to bring equality in the workplace. Even though there are more women graduates, the number of those joining the corporate sector and rising to the top remains abysmally low. (Thakur, 2020). In the recent study by Credit Suisse Research Institute (CSRI)India Ranked 23 globally, India's female representation on boards has increased by 4.3 percentage points over the past five years to $15.2 \%$ in 2019.Though female participation rate increased but it is significantly below the global average of $20.6 \%$ (Pathak 2019). India is near the bottom of the rankings for female representation at senior management levels, only marginally better than Japan and South Korea. Accepting the fact that female participation is top position is very less in India from the above figures this paper aims to examine the women in the top position as well as threw a light on area or type of work in which women are engaged in select service sector in Pune city.
\end{abstract}

Keywords: Women Participation, Glass Ceiling, Service sector, operative and non-operative work 


\section{Introduction:}

"Equal Participation of women in all field "- was the dream of Dr. A. P. J. Abdul Kalam. It is shocking yet true that as per latest report women comprises only $20.3 \%^{1}$ of the workplace in India in 2019 which was 26.45 in the year 2005. Women consist of $48 \%$ of Indian Population in 2020, nearly half. Isn't it wrong to keep the $30 \%$ of talents unutilized. Don't we feel that the economic growth of the country will increase if we make use of this unutilized hands. Actually, we are missing those talents due to chronic issue of gender disparity which is clear by the given data by World bank in the year $2016^{2}$.

\section{FIGURE I: MSSING WOMEN IN WORKFORCE ACROSS COUNTRIES}

\section{MISSING WOMEN}

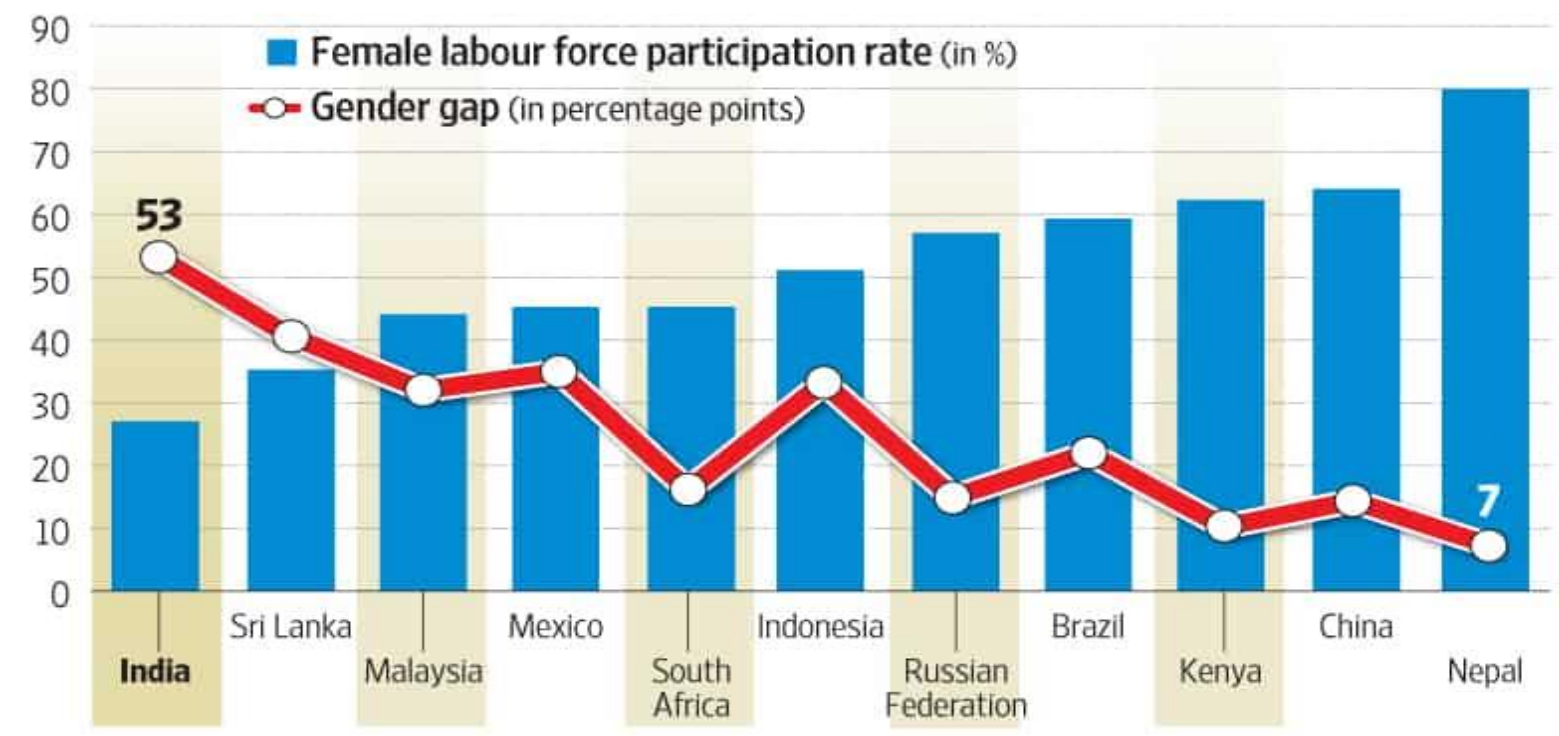

Source: World Development Indicators

It is surely a matter of concern that India is in a worst place in gender gap with 53\% which is not only worst when compared to developed European countries but also with Peer developing countries. "The world cannot afford the loss of the talents of half of people if we are to solve the many problems which beset us," said the eminent American scientist and Nobel Laureate Rosalyn Yalow. It will be applicable to India as well.

If we look into the fact majority of the working women in India falls under lower and middle level management. Glass celling is prevalent in almost all the sector in India. Some interesting facts about women in Top positions in India are.

- Only 3.7\% of CEOs and Managing Directors of NSE-listed companies were women in 2019, a number that has increased just slightly from $3.2 \%$ in $2014^{3}$

- $8.9 \%$ of firms have women in top management positions. ${ }^{4}$

- As of 2019, just 29 companies (5.8\%) on the Fortune India 500 list had women in executive roles. $^{5}$

- Women make up only $31 \%$ of Chief Human Resources Officers (CHROs), a role overrepresented by women in other countries such as the US and South Africa. ${ }^{6}$ 
- Women account for only $13.8 \%$ of board directors from listed companies in India. ${ }^{7}$

Accepting the fact that female participation is top position is very less in India from the above researches further this paper aims to through a light on area or type of work in which women are engaged in select service sector in Pune city. Being service sector is a sector where female participation is considerably high in India Telecommunication and Hospitality Industries are taken into consideration.

\section{RESEARCH OBJECTIVES:}

(1) Analysing the perception on the type of work (operative or non-operative) in which majority of women employees are employed at top level management position in select service sector in Pune district.

(2) To Undertake the inter group comparative analysis of the perception of the respondents.

\section{LITERATURE REVIEW:}

\section{Gender Bias in India in Top Positions:}

1.Sarika Malhotra, (2014), writing for the Business today under the caption - "Fewer Indian women at senior positions in workforce, finds report", have stated the following facts based on report of Grant Thornton India -

a. Women hold only $14 \%$ of the senior positions in 2014 as compared to $19 \%$ in 2013

b. Despite lot of talk to improve female participation in the workforce, $50 \%$ of Indian businesses don't have any program to support or mentor women nor do they plan to have one in the near future

c. Human Resource Director is the most popular position in the Indian Corporate world occupied by women, with $21 \%$ of these positions being led by women.

d. The article quotes study by McKinsey \& Co. who have stated that women representation on the board of Indian companies is as low as 5\%

e. Further according to the data compiled by Bloomberg, almost half of the top 100 companies on the BSE including the top 2, do not have a single women member on their Board.

\section{Areas of work for women at top management positions -}

Expert Agency Research -

1.Jenna Goudreau, (2011), in her post "20 surprising jobs women are taking over" has stated the following -

a. Surprisingly, women are taking over many jobs in finance that are often perceived as male-dominated. They comprise $54.7 \%$ of financial managers, $59.3 \%$ of budget analysts and $62.8 \%$ of insurance underwriters, according to the Women's Bureau reports. Although women may earn less on average than men in these positions - female financial managers earn $67 \%$ as much as male peers - the positions offer top workers the opportunity to earn six figures.

b. Another field where women are making a headway is that of medical sciences. They are not taking-up jobs like that of a surgeon which hitherto was restricted to men.

2. Sharon C Bolton, 2015, writing for the Washington Post has stated the following - 
a. A report by the ILO reveals that women hold 50 percent of middle management positions. But that is as far as equality extends, as less than 5 percent of chief executives of publicly listed companies in OECD countries are women and just 2.8 percent in the European Union. Britain's Chartered Management Institute reveals a gendered pyramid that is mirrored worldwide, with women holding positions as 60 percent of junior managers, 40 percent of middle managers, 20 percent at senior levels and single digits at chief executive.

b. In the same article the author has stated that it is the HR domain where women are in majority. However, beyond HR they have not made much progress.

\section{RESEARCH METHODOLOGY:}

The study is a Qualitative research for which the empirical approach was adopted. To realize the objectives of the research both the primary as well as secondary sources were utilized. The study was of select service sector organizations in Pune, namely, Telecom and Hospitality. The women employees of these organizations and the HR Managers constituted the Population. Hospitality organizations in Pune - 5 star and 4 star Hotels were selected as the population in view of their big size and professional management.

TABLE I: POPULATION SUMMARY

\begin{tabular}{|l|l|l|l|l|}
\hline Sr. No. & Category & Sub-category & $\begin{array}{l}\text { Number } \\
\text { of units }\end{array}$ & $\begin{array}{l}\text { Number of } \\
\text { women } \\
\text { employees }\end{array}$ \\
\hline 1 & Telecommunication & --- & 30 & 300 \\
\hline 2 & Hospitality & & & \\
\hline $2 \mathrm{a}$ & & 5-star Hotels & 24 & 240 \\
\hline $2 \mathrm{~b}$ & & 4-star Hotels & 44 & 440 \\
\hline & Total & & 98 & 980 \\
\hline
\end{tabular}

Roughly there are 100 such organizations in the 2 service sectors and at an average of 10 women employees, the total population is estimated to be 1000. Assuming $1 \mathrm{HR}$ manager per unit, the total population of the HR managers is estimated to be around 100. It is conservatively assumed that each of the company on an average employs 10 women employees each.

\section{SAMPLE SELECTION}

Samples of 50 HR Managers and from 300 women employees were both random sampling selected. Following methodology for sample selection was adopted. A complete list of the 98 units was generated and sorted them in alphabetical order. Sample size of 50 HR managers (50\%) and 300 women employees (30\%) was selected. unique 75 random numbers were and these 75 units based on random numbers generated. The survey of first $50 \mathrm{HR}$ managers and 300 women employees were administered to these 75 randomly selected companies. 


\section{QUESTIONNAIRE DESIGN}

The questionnaire was designed in MS Excel using data validation option for checking entry of responses at the time of entry itself.

A structured questionnaire which comprised of series of questions related to the perception employees and HR hold about the type of work performed by the women in higher position. The questions were rated on the four-point scale.

TABLE II: FOUR POINT SCALE USED IN QUESTIONNAIRE

\begin{tabular}{|c|c|}
\hline 0 & No response \\
\hline 1 & Somewhat agree \\
\hline 2 & Completely agree \\
\hline 3 & Somewhat disagree \\
\hline 4 & Completely disagree \\
\hline
\end{tabular}

\section{DATA ANALYSIS AND MODEL ADOPTED FOR STATISTICAL TESTING -}

For the purpose of data analysis, the responses were aggregated and, assigned weights of 1.50 each to completely agree and completely disagree responses. Calculate the percentages of total agrees and total disagrees (taking into account weight of 1.50 for each of the "completely" response). the null hypothesis was set with a value of 0.50 indicating that the percentages of agree and disagree are same, that is to mean that, there is no significant differences.

There are different types of statistical tests for hypotheses testing under different scenarios. In the current situation, the researcher had to evaluate the mean of the sample where standard deviation of the population is not known but standard deviation of the sample can be calculated. The methodology for testing the mean with standard deviation of population unknown is adopted P-Value Method using the t-Distribution-Hypothesis Test Regarding $\mu$ with $\sigma$ Unknown

\section{HYPOTHESIS:}

\section{Null Hypothesis:}

The highest-ranking women in most of the companies are employed in operating and nonoperating areas in select service sector

\section{Alternate Hypothesis:}

The highest-ranking women in most of the companies are employed in only non-operating areas in select service sector. 


\section{PROFILE OF RESPONDENTS:}

The profile of the respondents had been analyzed for the two parameters viz gender and industry in which employees and HR Manager were working. Table summarizes the representation of the respondents.

TABLE III: DEMOGRAPHIC PROFILE OF THE RESPONDENTS

\begin{tabular}{|c|c|c|c|}
\hline S no & Parameters & & \\
\hline 1 & Gender & Women (\%) & $\operatorname{Men}(\%)$ \\
\hline & & 56 & 44 \\
\hline 2 & Industry wise classification & Hospitability (\%) & $\begin{array}{c}\text { Telecommunication } \\
(\%)\end{array}$ \\
\hline & Employees & $50(149)$ & $50(150)$ \\
\hline & HR Managers & $52(24)$ & $48(26)$ \\
\hline
\end{tabular}

\section{DATA ANALYSIS AND DISCUSSIONS}

\section{(I) Test of reliability \& Validity}

Cronbach's Alpha and other tests were applied on various parts of the questionnaire using "Siegle Reliability Calculator" an excel program and the results are summarized as under Measurement of reliability for the questionnaire taken together - (employees) came out to be 0.892 for the female women employees and for HR mangers is 0.8770 .The sets received from both the samples of the employees and HR Mangers are reliable so questionnaire can be further used for the purpose of data collection. All the responses were sought by way of selection of programmed pop-up selection menu. No manual entry was permitted. Names were not taken for the sake of confidentiality.

\section{(II) Responses from the data Collection:}

The Table IV displays in percentage the responses regarding respondent's observation about women working in top position. Whether in high position women working are from service or operative area. The responses are basically of female HR employees and HR managers from the selected Service sector from Pune.

These data sets were further utilized for the purpose of comparative analysis and hypothesis testing. 


\begin{tabular}{|c|c|c|c|c|c|c|}
\hline \multicolumn{7}{|c|}{ TABLE IV: RESPONSES FOR THE PERCEPTION OF RESPONDENTS } \\
\hline & & $\begin{array}{c}\text { No } \\
\text { Respons } \\
\mathrm{e} \\
(\%)\end{array}$ & $\begin{array}{c}\text { Somewh } \\
\text { at Agree } \\
(\%)\end{array}$ & $\begin{array}{c}\text { Complete } \\
\text { ly Agree } \\
(\%)\end{array}$ & $\begin{array}{c}\text { Somew } \\
\text { hat } \\
\text { Disagre } \\
\mathrm{e} \\
(\%)\end{array}$ & $\begin{array}{c}\text { Complete } \\
\text { ly } \\
\text { Disagree } \\
(\%)\end{array}$ \\
\hline \multirow[t]{3}{*}{1} & \multicolumn{6}{|c|}{ High ranking jobs are mostly employed in service areas (HR, Admin. etc.) } \\
\hline & Female Employees Responses & 1.67 & 17.00 & 64.67 & 8.67 & 8.00 \\
\hline & HR Managers Responses & 0 & 36 & 46 & 14 & 4 \\
\hline \multirow[t]{3}{*}{2} & \multicolumn{6}{|c|}{ Women are more suitable for service areas rather than operations } \\
\hline & Female Employees Responses & 2.67 & 17.00 & 19.67 & 22.00 & 38.67 \\
\hline & HR Managers Responses & 0 & 24 & 26 & 28 & 22 \\
\hline \multirow[t]{3}{*}{3} & \multicolumn{6}{|c|}{$\begin{array}{l}\text { Top management positions are almost every time filled-up from the operating areas of the } \\
\text { business only }\end{array}$} \\
\hline & Female Employees Responses & 2.00 & 20.67 & 44.67 & 12.67 & 20.00 \\
\hline & HR Managers Responses & 6 & 14 & 64 & 10 & 6 \\
\hline \multirow[t]{3}{*}{4} & \multicolumn{6}{|c|}{$\begin{array}{l}\text { Difficult for women to occupy top ranks in core operating areas like production and } \\
\text { marketing }\end{array}$} \\
\hline & Female Employees Responses & 2.33 & 43.00 & 7.00 & 19.33 & 28.33 \\
\hline & HR Managers Responses & 4 & 36 & 0 & 28 & 32 \\
\hline \multirow[t]{3}{*}{5} & \multicolumn{6}{|c|}{$\begin{array}{l}\text { Over the last } 10 \text { years or so there has been change in the perception that women are not } \\
\text { suitable for core areas }\end{array}$} \\
\hline & Female Employees Responses & 2.67 & 17.00 & 28.00 & 18.33 & 34.00 \\
\hline & HR Managers Responses & 0 & 22 & 30 & 28 & 20 \\
\hline \multirow[t]{3}{*}{6} & \multicolumn{6}{|c|}{$\begin{array}{l}\text { Women should be given reasonable opportunities in core areas of business right from the start } \\
\text { of their career }\end{array}$} \\
\hline & Female Employees Responses & 2.00 & 38.33 & 22.00 & 18.33 & 19.33 \\
\hline & HR Managers Responses & 0 & 42 & 24 & 26 & 8 \\
\hline 7 & \multicolumn{6}{|c|}{ Women can be accommodated at the top areas in core operations but in an advisory capacity } \\
\hline & Female Employees Responses & 1.67 & 36.00 & 27.67 & 17.67 & 17.00 \\
\hline & HR Managers Responses & 0 & 42 & 28 & 24 & 6 \\
\hline
\end{tabular}

\section{(III) Inter Group Comparison of the perception}

To understand and analyze the perception of the respondents in more detailed way intergroup comparison was done for -
(A) Employees \& HR Managers
(B) Telecom and Hospitality industry employees

For the purpose of comparison responses cumulative percentage for somewhat agrees and completely agrees has been considered. 


\section{(A) Employees and HR Managers}

\section{GRAPH I: - WOMEN WORKING IN SERVICE AREAS (EMPLOYEES \&HR MANAGERS)}

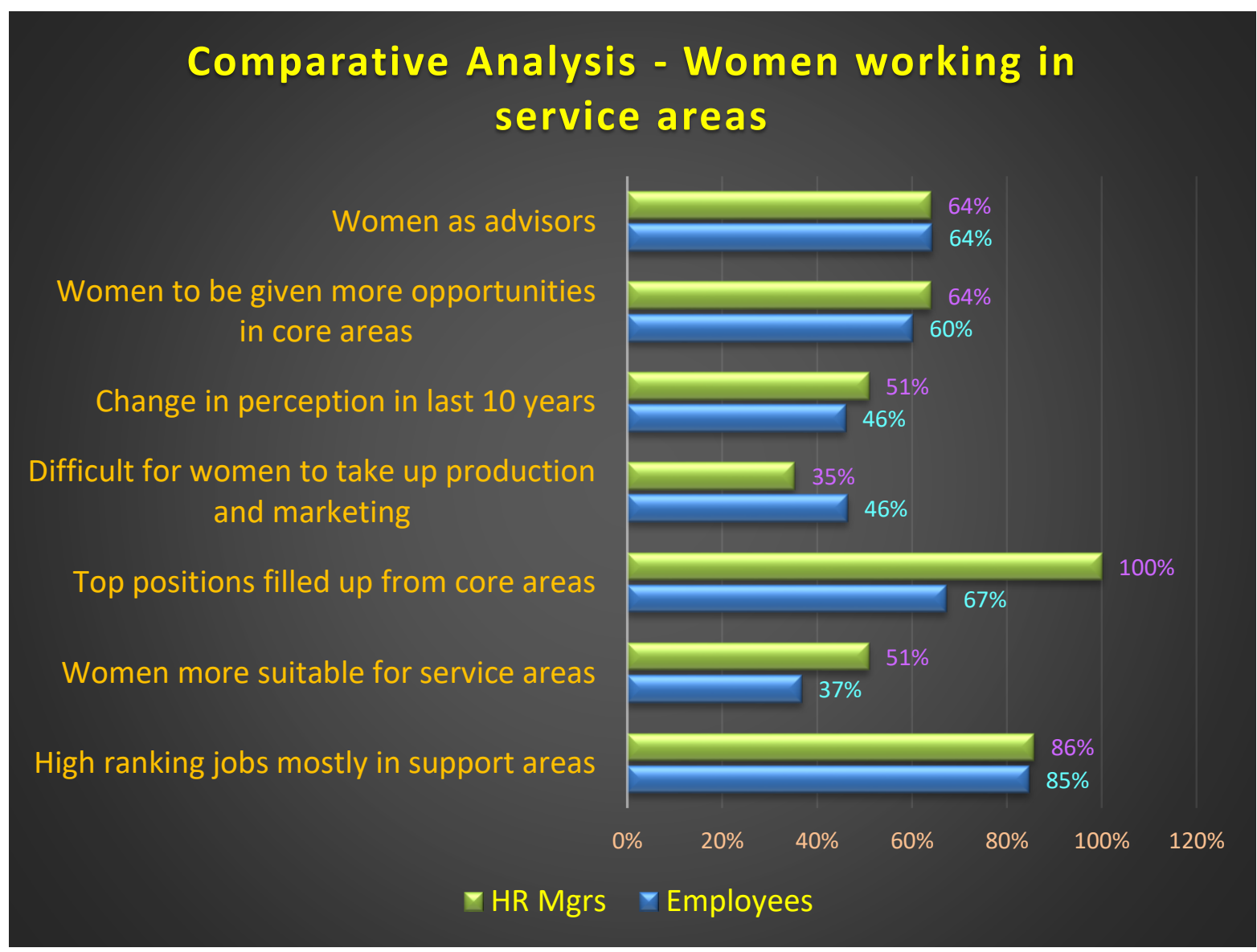

It is evident from the Graph I for the response from the HR Managers and Employees is very much on similar pattern. Both the employees as well as the HR mangers are in congruence with their feelings on the issues of women working in top position in the industry of research. Employees and HR Manager (64\%) feels that women at top level are in advisory role and mostly they work in support areas only this, means that both feel women in top ranks are engaged in HR or administrative roles (Employees $85 \%$ \& HR managers $86 \%$ ) rather than taking core position in marketing or operations. In alignment to this both share same perception that the women should be provided more opportunities in operative managerial function as well (Employees $60 \%$ \& HR managers 64\%).

There are certain issues where both have different and totally varied perception. Only Employees (67\%) and HR mangers (100\%) feels that the higher-level ranks should be filled by the women from the core areas also. Both the group also have different opinion for the issues like women are more suitable to take up service-related jobs rather than operations. 
(B) Telecom and Hospitality industry employees (Intra-group comparison)

\section{GRAPH II: - WOMEN WORKING IN SERVICE AREAS(INDUSTRYWISE)}

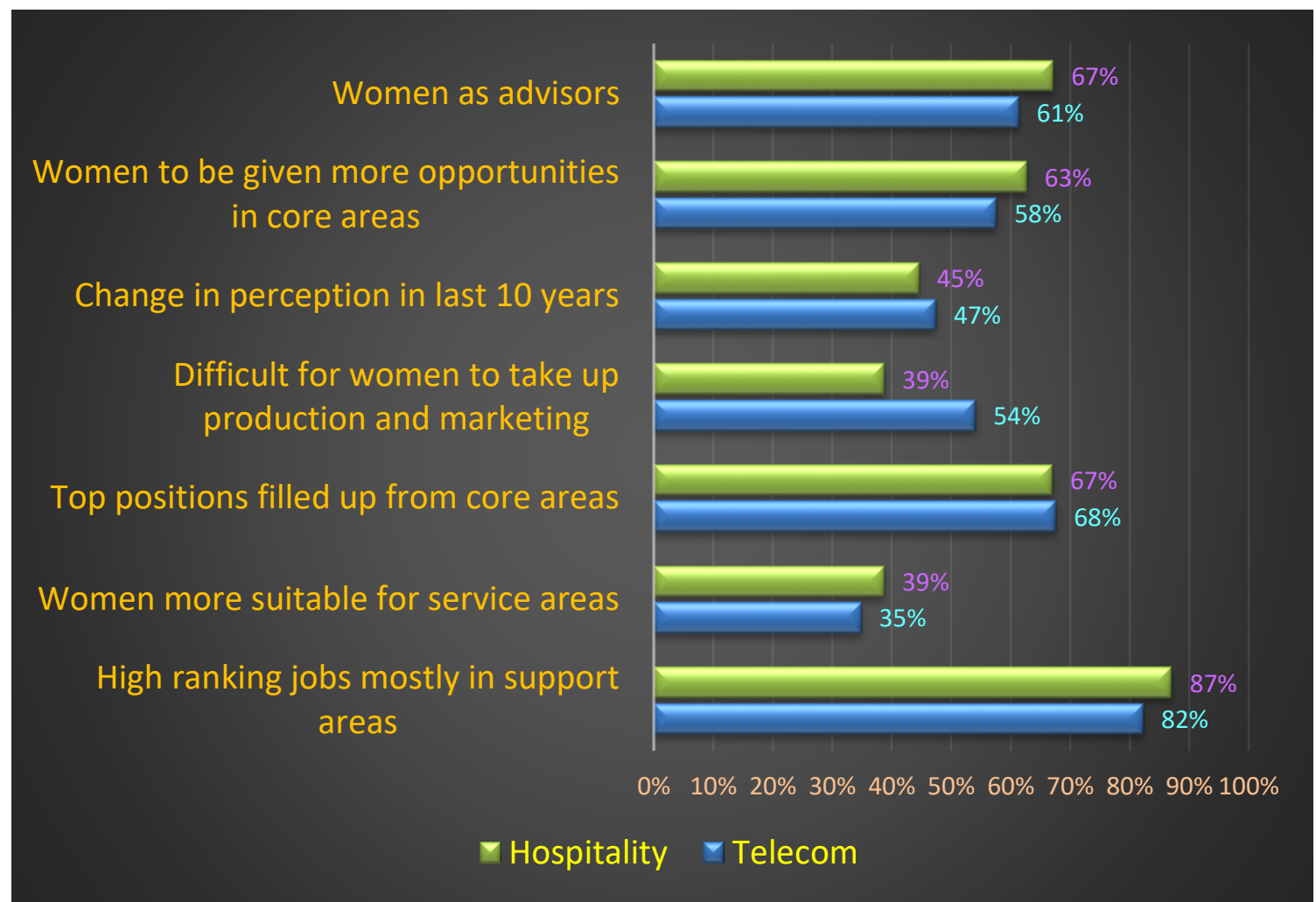

The two groups under study ie Hospitality and telecom when compared for their perception regarding women taking higher ranks and position form service or operations depicted agreements on most of the issues under study as evident form the graph II. For almost all the parameters both group feels the same Both feel that top positions should be filled from the core areas Hospitality (67\%) and Telecom (68\%) followed by that there has been change in perception in last ten years about women suitability to fill up top ranks from the core areas Hospitality (45\%) and Telecom (47\%)

One perception is not so much in congruence for is that hospitability (39\%) is in less agreement in comparison to the telecom industry $(54 \%)$ on the issue of that it is difficulty for the women to occupy top position in the core areas.

Other factors the difference in agreement on the various issues among to the group ranges for marginal $4 \%$ to $5 \%$ which can be considered not so much difference. 


\section{(IV) Testing of Hypothesis}

Ho - The highest-ranking women in most of the companies are not only in non-operating areas in select service sector

$\mathrm{Ha}$ - The highest-ranking women in most of the companies are in non-operating areas only in select service sector

Statistical testing of significance - (@ 95\% level of confidence)

TABLE V: STATISTICS FOR HYPOTHESIS TESTING

\begin{tabular}{|l|c|c|}
\hline \multicolumn{1}{|c|}{ Parameter } & Women employees & HR Managers \\
\hline $\mathrm{H} 1=$ & 0.85 & 0.84 \\
\hline $\mathrm{SD}$ & 0.802247 & 0.808375 \\
\hline $\mathrm{Ho}=$ & 0.5 & 0.5 \\
\hline $\mathrm{H} 1=$ & 0.85 & 0.84 \\
\hline $\mathrm{N}$ & 300 & 50 \\
\hline $\mathrm{t}$-dist & 7.09 & 2.86 \\
\hline $\mathrm{p}$-value & 0.000000 & 0.003087 \\
\hline Is p-value $<0.05$ & Yes & Yes \\
\hline Accept/Reject Ho & Reject Ho & Reject Ho \\
\hline
\end{tabular}

\section{For Women employees}

Calculated $\mathrm{p}$ value for the women employee perception for various parameters for hypothesis testing is .000 which is less than alpha value of 0.05 at $95 \%$ significant level which means we reject null hypothesis and approve alternative hypothesis that in service sector viz telecom and hospitality industry of Pune women in high position are in non-operating areas only. This also approve the literature reviewed that the women in high position in service sector are only working in HR or administrative roles and there is dearth of their managerial roles in operative function of management viz marketing or in production.

\section{For HR Managers}

Calculated $\mathrm{p}$ value for the HR mangers perception for various parameters for hypothesis testing is .003 which is less than alpha value which means of 0.05 at $95 \%$ significant level we reject null hypothesis and approve alternative hypothesis that in service sector viz telecom and hospitality industry of Pune women in high position are in non-operating areas only. This also approve the literature reviewed that the women in high position in service sector are only working in HR or administrative roles and there is dearth of their roles in operative function of management in marketing or in production.

So, we can conclude on the basis of hypothesis testing that women working in high position are from service. In other words, it is true that they are working only in service areas. 


\section{CONCLUSION:}

Through this research it can be concluded that Women is yet to play a vital role in contributing the development of Indian economy. The government of India has is also taking various steps in major areas like education, promoting women entrepreneurs, Judicial enforcement of minimum one women director in the board etc. India can move forward in ensuring bridging the gender gap provided men and women of India have a open mindset to encourage participation of women in Labour force.

\section{References:}

1. World Bank Group, "Labor Force, Female (\% of Total Labor Force) - India," The World Bank Databank (2020).

2.https://www.livemint.com/Opinion/BzaAvDjwguk3YdnSXSR8sN/The-217-million-missingwomen-in-Indias-workforce.html

3. Prachi Verma and Sreeradha D. Basu, "At Only 3\%, Corporate India Is Still Struggling to Bring Women to the Top," The Economic Times, March 17, 2019.

4. World Economic Forum, "Data Explorer: India," The Global Gender Gap Report 2020 (2020).

5. Arnika Thakur, "Fortune India 500: Why Are There So Few Women Leaders?" Fortune, January 5, 2020.

6. Atul Bhandari and Sachi Chopra, "India CHRO Route to the Top: The Rise of the MultiDimensional HR Leader, ” Spencer Stuart, August 2020.

7. World Economic Forum, "Data Explorer: India," The Global Gender Gap Report 2020 (2020).

8. Pathak Kalpana(2019), https://www.livemint.com/companies/news/india-lags-in-femalerepresentation-in-senior-management-credit-suisse-report-11570712711545.html

9. Thakur Arnika , 2020https://www.fortuneindia.com/people/fortune-india-500-why-arethere-so-few-women-leaders/103961 